\section{Regarding the Ambiguity of the Medical Terms "Biologics" and "Biological Agents"}

Key words: biologics, biological agents, molecular targeted therapy, monoclonal antibodies, recombinant fusion proteins, small-molecule kinase inhibitors

\section{(Intern Med 55: 2327, 2016)}

(DOI: 10.2169/internalmedicine.55.6841)

To the Editor I read with interest the articles by Bannai et al. (1) and Kobayashi et al. (2) in volume 54, number 20 of Internal Medicine.

These articles cover monoclonal antibody therapy for patients with adult-onset Still's disease $(1,2)$. I speculate that the authors of the two articles used the terms "biologics" or "biological agents" idiomatically, following the example in the guidelines for the treatment of rheumatoid arthritis from the American College of Rheumatology (3), as opposed to as in molecular targeted therapy based on monoclonal antibodies, recombinant fusion proteins, or both.

Currently, a great number of molecular targeted therapies, which depend on monoclonal antibodies, recombinant fusion proteins, and small-molecule kinase inhibitors, are being developed for rheumatoid arthritis, autoimmune diseases, and malignancies.

I harbor doubts about using the terms "biologics" or "biological agents" with the sole meaning of molecular targeted therapy based on monoclonal antibodies, recombinant fusion proteins, or both. This is due to the fact that the U.S. Food and Drug Administration (FDA) defines "biologics" as biologic products including a wide range of products, such as vaccines, blood and blood components, allergenics, somatic cells, gene therapies, tissues, and recombinant therapeutic proteins (4), as well as monoclonal antibodies. The American Medical Association (AMA) explains "Naming Biologics" on their website by citing the statement of the United States Adopted Names (USAN) Council (5). They include insulins, interferons, interleukins, growth hormones, colony- stimulating factors, cytokines, monoclonal antibodies, and coagulation factors under the term "biologics". This is how the FDA and the AMA clearly define "biologics".

Moreover, in the Medical Subject Headings $\left(\mathrm{MeSH}^{\circledR}\right)$ thesaurus, a controlled vocabulary established by the United States National Library of Medicine, the MeSH for "Biological Products" includes "Biologics", "Molecular Targeted Therapy", "Antibodies, Monoclonal", and "Recombinant Fusion Proteins" as separate items.

Defining "biologics" both narrowly and broadly can certainly confuse the readers. For the sake of clarity in scientific writing, specifically defining the medical terms used is important. When authors use "biologics" or "biological agents" to refer to molecular targeted therapy specifically based on monoclonal antibodies, recombinant fusion proteins, or both rather than to biological products in general, they should clearly state so when the terms first appear in their articles.

The author states that he has no Conflict of Interest (COI).

Hitoshi Sugawara

\section{References}

1. Bannai E, Yamashita H, Takahashi Y, Tsuchiya H, Mimori A. Two cases of adult-onset Still's disease with orbital inflammatory lesions originating from the lacrimal gland. Intern Med 54: 26712674, 2015.

2. Kobayashi D, Ito S, Murasawa A, Narita I, Nakazono K. Two cases of adult-onset Still's disease treated with tocilizumonoclonal antibodies that achieved tocilizumonoclonal antibodies-free remission. Intern Med 54: 2675-2679, 2015.

3. Singh JA, Saag KG, Bridges SL, et al. 2015 American College of Rheumatology Guideline for the Treatment of Rheumatoid Arthritis. Arthritis Rheumatol 68: 1-26, 2016.

4. U.S. Food and Drug Administration. What Are "Biologics" Questions and Answers [Internet]. [cited 2015 Nov. 14]. Available from: http://www.fda.gov/AboutFDA/CentersOffices/OfficeofMedic alProductsandTobacco/CBER/ucm133077.htm

5. American Medical Association. Naming Biologics [Internet]. [cited 2015 Nov. 22]. Available from: http://www.ama-assn.org/ama/pub/ physician-resources/medical-science/united-states-adopted-names-c ouncil/naming-guidelines/naming-biologics.page?

Division of General Medicine, Department of Comprehensive Medicine 1, Saitama Medical Center, Jichi Medical University, Japan Received for publication November 15, 2015; Accepted for publication November 30, 2015

Correspondence to Dr. Hitoshi Sugawara, hsmdfacp@omiya.jichi.ac.jp

(C) 2016 The Japanese Society of Internal Medicine Journal Website: http://www.naika.or.jp/imonline/index.html 